\title{
Studies of the growth-promoting activity for chicks of fish solubles
}

\author{
BY G. F. HARRISON AND M. E. COATES \\ National Institute for Research in Dairying, Shinfield, Reading \\ (Received 4 March 1964-Accepted 6 April 1964)
}

The presence of unidentified growth factors in fish solubles has been postulated for more than a decade (Sunde, Cravens, Elvehjem \& Halpin, 1950; Fuller, Carrick \& Hauge, I952; Lillie, Sizemore \& Bird, 1953). During this period several attempts have been made to fractionate and concentrate the active constituents (Menge, Denton, Sizemore, Lillie \& Bird, 1953; Mason, Sacks \& Stephenson, I96r ; Steinke, Bird \& Strong, 1963) but so far they remain uncharacterized. We report here the results of our investigations, done over several years, into the growth-promoting effects of herring solubles.

\section{EXPERIMENTAL}

\section{Chicks and diets}

Day-old Rhode Island Red $\times$ Light Sussex birds of both sexes were used in all experiments. They were housed in electrically heated tier brooders and had free access to food and water. The birds were weighed at weekly intervals, and the tests ended at 4 weeks. A few experiments were done with normal chicks hatched from hens given a practical breeder's diet. However, on the assumption that the growth factors in fish solubles might also be present in concentrated sources of animal proteins in general and might be stored in the egg, for most of these experiments chicks (referred to as 'depleted') were from hens maintained on a diet containing proteins of vegetable origin only. It had the percentage composition: maize 22, wheat 20 , oats 20 , soya grits 25, dried grass 5 , bone meal 4.25 , salts $\left(\mathrm{NaCl} 213.3 \mathrm{~g}, \mathrm{MnSO}_{4} \cdot{ }_{4} \mathrm{H}_{2} \mathrm{O} \mathrm{I}_{3} \cdot 6 \mathrm{~g}\right.$, $\mathrm{KI} 0.13^{6} \mathrm{~g}$ ) 0.5 , vitamin concentrate (to contribute 363200 i.u. vitamin A, go800 i.u. vitamin $\mathrm{D}_{3}, \mathrm{I} 34 \mathrm{mg}$ riboflavine/100 lb) $\mathrm{I}$.

Two types of basal chick diet were used. One was an all-vegetable protein diet, composed of $(\%)$ : maize $37 \cdot 8$, barley 20 , defatted soya grits 35 , dried grass 3 , bone meal $I \cdot 5$, limestone 1 , arachis oil (containing 64 i.u. vitamin $\mathrm{D}_{3}$ and $680 \mathrm{i} . u$. vitamin A/g) I, $\mathrm{NaCl} 0.672$ and $\mathrm{MnSO}_{4} .{ }_{4} \mathrm{H}_{2} \mathrm{O} 0.028$. It was supplemented with vitamins $(\mathrm{mg} / \mathrm{I} 00 \mathrm{~g}$ ) as follows: biotin 0.022 , folic acid 0.083 , thiamine 0.33 , pyridoxine 0.44 , riboflavine 0.77 , calcium pantothenate 1.65 , nicotinic acid 5.5 , cyanocobalamin 0.002 . The other was a more usual chick-rearing mash, with the percentage composition: maize 35 , wheat 30 , miller's offals $8 \cdot 5$, fish meal 10, dried skim milk $7 \cdot 5$, dried grass 3 , dried brewer's yeast 3 , limestone $\mathrm{I} \cdot 5$, salt mixture $\left(\mathrm{NaCl} 93 \cdot 94, \mathrm{MnSO}_{4} \cdot{ }_{4} \mathrm{H}_{2} \mathrm{O} 6\right.$, $\mathrm{KI} 0.06 \%$ ) 0.5 , arachis oil (containing 64 i.u. vitamin $\mathrm{D}_{3}$ and 680 i.u. vitamin $\mathrm{A} / \mathrm{g}$ ) $\mathrm{r}$.

The sample of fish solubles used throughout these studies was of Norwegian origin 
and was representative of good-quality condensed herring solubles, as commercially available. It was added, at the expense of whole diet, at a evel of $5 \%$ except in three early experiments when $3 \%$ was used. Fractions were incorporated at levels equivalent to $5 \%$ original solubles. In the earlier experiments penicillin was added at the rate of $25 \mathrm{mg} / \mathrm{kg}$ diet. This is considerably in excess of the amount needed to give maximal growth response, and so in later work the level was reduced to $10 \mathrm{mg} / \mathrm{kg}$. There was no difference in the magnitudes of response to the two doses, and the results with both have therefore been treated together.

\section{Preparation of fractions}

'To separate water-soluble from insoluble material, in the eariy experiments the intact herring solubles were mixed with an equal volume of tap water. The diluted solubles were then either passed through a cream separator or spun in a centrifuge at $115 \circ \mathrm{g}$ for $45 \mathrm{~min}$. To avoid the fatty material appearing in the supernatant layer, in later experiments the fish solubles were freeze-dried and extracted with either light petroleum $\left(40-60^{\circ}\right)$ or chloroform-methanol $2: 1$. The dried extracted residue was then blended with ten times its weight of water and separated in a centrifuge as before. 'The supernatant layer was freeze-dried and the residue mixed with a little water to facilitate incorporation into the diet.

\section{Arrangement of experiments}

There were two sets of experiments with normal chicks and two sets with depleted chicks. With each type of chick the two sets of experimen:s consisted of those in which the basal diet was all-vegetable and those in which the rormal type of basal diet was used. The experimental groups usually contained from eight to twelve chicks and were replicated whenever possible (Table I).

Table I. Total number of experiments with each :ype of chick and diet, and numbers of replicates used in the statistical analysis

\begin{tabular}{|c|c|c|c|c|}
\hline \multirow[b]{2}{*}{ Treatment } & \multicolumn{2}{|c|}{ Normal chicks } & \multicolumn{2}{|c|}{ Depleted chicks } \\
\hline & $\begin{array}{c}\text { Normal } \\
\text { diet }\end{array}$ & $\begin{array}{c}\text { Vegetable- } \\
\text { protein } \\
\text { diet }\end{array}$ & $\begin{array}{l}\text { Normal } \\
\text { diet }\end{array}$ & $\begin{array}{c}\text { Vegetable- } \\
\text { protein } \\
\text { diet }\end{array}$ \\
\hline A, basal diet & 9 & 7 & 3 & 55 \\
\hline B, basal diet + fish solubles & 9 & 7 & 3 & 55 \\
\hline C, basal diet + penicillin & 9 & I & 3 & 19 \\
\hline D, basal diet + fish solubles + penicillin & 4 & o & 0 & 9 \\
\hline $\begin{array}{l}\text { E, basal diet + water-soluble extract of fish } \\
\text { solubles }\end{array}$ & 0 & $\circ$ & $\circ$ & 22 \\
\hline $\begin{array}{l}\text { F, basal diet + water-insoluble extract of fish } \\
\text { solubles }\end{array}$ & 0 & $\circ$ & $\circ$ & 23 \\
\hline Total no. of experiments & 4 & 4 & 3 & 28 \\
\hline
\end{tabular}

Statistical analysis

The analyses of variance were carried out for mean weights of chicks at 4 weeks of age. For depleted chicks receiving the normal diet the three imposed treatments were 
equally represented in each experiment, but in the other chick categories the treatments were not equally represented (see 'Table $\mathrm{r}$ ) and results were analysed by least squares methods appropriate to non-orthogonal data. Differences between treatment means were tested for significance by the multiple-range test (Duncan, 1955; Kramer, 1957).

\section{RESULTS}

We present in Table 2 the mean values and their standard errors for all treatments and the results of significance tests. Treatment effects, that is, differences from values obtained with the basal diet, are given in Table 3. In experiments with depleted chicks on vegetable-protein diet, all supplements caused significant increases in

Table 2. Mean weights, with their standard errors, $(g)$ at 4 weeks of chicks receiving supplements of fish solubles with or without procaine penicillin

Treatment

A, basal diet

B, basal diet + fish solubles

C, basal diet + penicillin

$\mathrm{D}$, basal diet + fish solubles

+ penicillin

E, basal diet + water-soluble extract of fish solubles

$F$, basal diet + water-insoluble extract of fish solubles

Degrees of freedom for standard errors

Test for significance*

$\overbrace{\begin{array}{c}\text { Normal } \\ \text { diet }\end{array}}^{\text {Normal chicks }} \begin{array}{c}\text { Vegetable- } \\ \text { protein diet }\end{array}^{\text {proting }}$

$\begin{array}{cc}273 \cdot 7 \pm 3 \cdot 69 & 303 \cdot 8 \pm 5 \cdot 79 \\ 304 \cdot 2 \pm 3 \cdot 69 & 324 \cdot 0 \pm 5 \cdot 79 \\ 287 \cdot 1 \pm 3 \cdot 69 & 313 \cdot 9 \pm 16 \cdot 76 \\ 316 \cdot 6 \pm 5 \cdot 91 & - \\ - & - \\ - & - \\ 17 & 6\end{array}$

$\begin{array}{ll}\text { A } & \text { A } \\ \text { C } & \text { C } \\ \text { B } & \text { B } \\ \text { D } & \end{array}$

\begin{tabular}{cc}
\multicolumn{2}{c}{ Depleted chicks } \\
$\begin{array}{c}\text { Normal } \\
\text { diet }\end{array}$ & $\begin{array}{c}\text { Vegetable- } \\
\text { protein diet }\end{array}$ \\
$\begin{array}{cc}287 \cdot 0 \pm 3 \cdot 46 & 317 \cdot 4 \pm 1 \cdot 82 \\
326 \cdot 3 \pm 3 \cdot 46 & 338 \cdot 1 \pm 1 \cdot 82 \\
302 \cdot 7 \pm 3 \cdot 46 & 337 \cdot 6 \pm 3 \cdot 41\end{array}$ \\
- & $356 \cdot 9 \pm 5 \cdot 06$ \\
- & $325 \cdot 5 \pm 3 \cdot 20$ \\
- & $328 \cdot 5 \pm 3 \cdot 16$ \\
4 & 89 \\
A & A \\
C & E \\
B & F $!$ \\
& C! \\
& B $\left.\right|_{\mid}$ \\
& D
\end{tabular}

- Mean values of treatments coupled by the same line are not significantly different at $P=0.05$.

Table 3. Effects (mean values with their standard errors) on weight of chicks ( $g$ ) of supplements of fish solubles with or without procaine penicillin

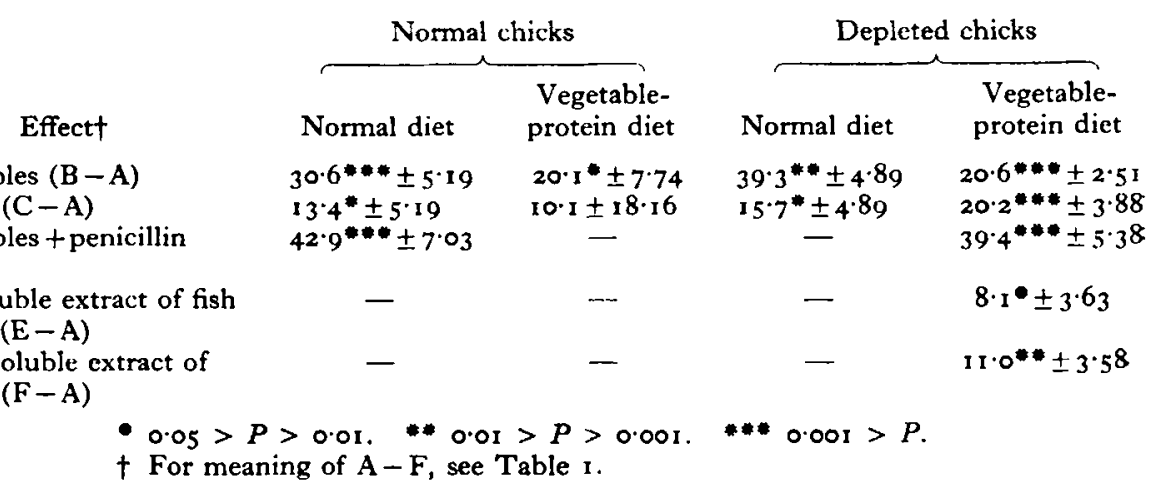

Fish solubles $(B-A)$

Penicillin (C-A)

Fish solubles + penicillin (D-A)

Water-soluble extract of fish solubles $(E-A)$

Water-insoluble extract of solubles $(\mathrm{F}-\mathrm{A})$ 
weight relative to those on the basal diet. Both fractions of solubles were equally active, to the extent of about half that of the original material. The growth effect of the solubles $(20.6 \mathrm{~g})$ was similar to that of penicillin $(20.2 \mathrm{~g})$; when solubles and penicillin were given together, their combined effect $(39.4 \mathrm{~g})$ was approximately double that due to either alone. Depleted chicks on normal diet showed a marked response to fish solubles $(39.3 \mathrm{~g})$, and the growth response to penicillin ( $15.7 \mathrm{~g}$ ) was also significant but less pronounced.

The results for normal chicks show that the addition of fish solubles to either the normal or the vegetable-protein diet significantly improved gains in weight $(30.6$ and $20.1 \mathrm{~g}$ respectively), but the effects of penicillin ( $13.4 \mathrm{~g}$ with normal diet and $10.1 \mathrm{~g}$ with vegetable-protein diet) were less marked. The pen icillin effect on normal chicks receiving vegetable-protein diet failed to reach significance, but this finding is based on the evidence of only one group. When both supplements were added to the normal diet, their combined effect $(42 \cdot 9 \mathrm{~g})$ was approximately the sum of their separate effects $(44 \cdot 0 \mathrm{~g})$.

Of the twenty-eight experiments done with depleted chicks given the vegetableprotein diet, eleven permit comparison between the effects of fish solubles and of penicillin. Examination of these results shows a striking similarity between the magnitude of the growth response to fish solubles and to penicillin in any one experiment. This relationship is illustrated in Fig. $r$.
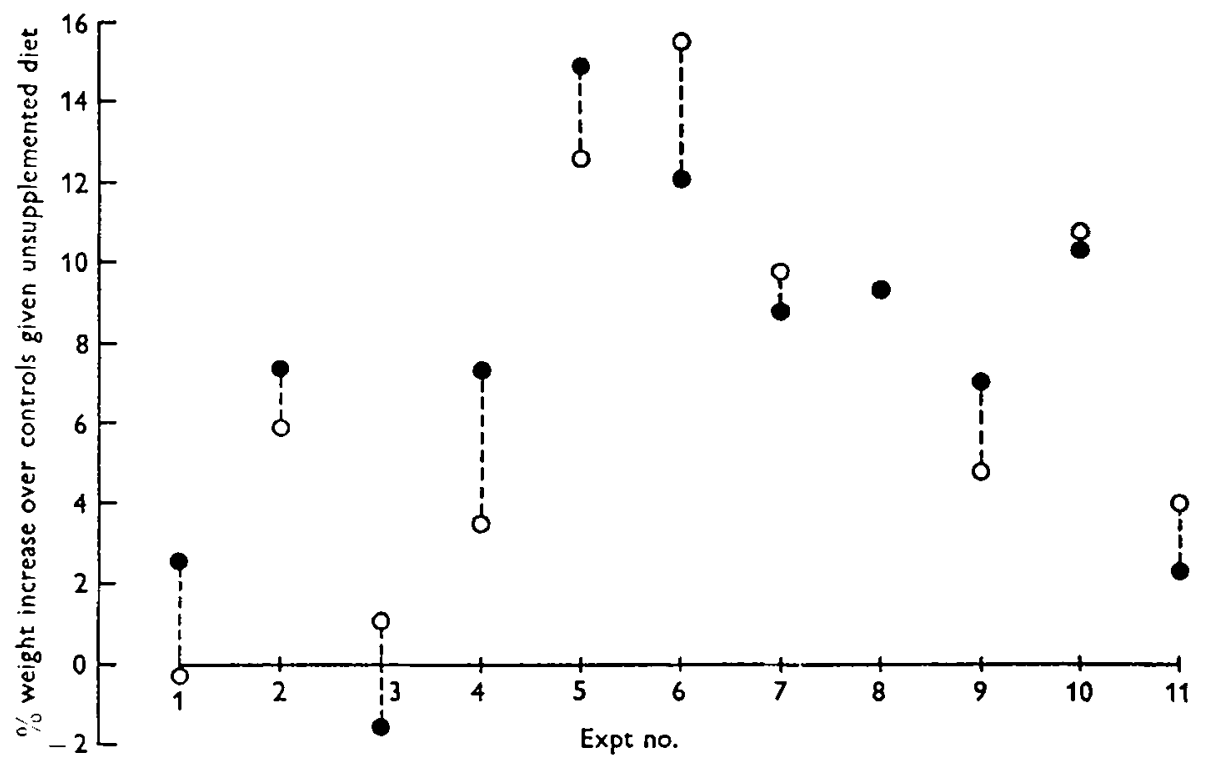

Fig. I. Comparison of growth response (\%) of chicks to supplements of fish solubles or penicillin in a vegetable-protein diet in eleven separate experiments. $\bullet$, fish solubles; 0 , penicillin.

DISCUSSION

The results reported here add further evidence that fish solubles can increase the growth of chicks given diets believed adequate in all known essentials. Our finding that the activity is about equally divided between fractions soluble and insoluble in 
water is in agreement with those of Menge et al. (1953) and Steinke et al. (1963) and might be interpreted in terms of a multiplicity of factors responsible for the growthpromoting properties of fish solubles. Alternatively, if only one active principle is involved, it may be strongly adsorbed on the insoluble component or only sparingly soluble in water. With these possibilities in mind, further fractionation is being attempted.

A striking aspect of our results is the variation in growth response to fish solubles, which, in depleted chicks on vegetable-protein diet, ranged from $-1.5 \%$ to $+15.6 \%$. Barnett \& Bird (1956) and Steinke et al. (1963) noted a similar variation. Waibel, Morrison \& Norris (1955) have commented on '...the well-known, but usually unpublished, difficulties in studying unidentified chick growth factors... These difficulties have been attributed to large reserves of such factors in chicks obtained from hens receiving a normal diet and to the influence of the microflora of the gastrointestinal tract, which may vary in different environments.

Several groups of investigators have presented evidence that reserves of unidentified growth factors are carried over in eggs from hens on diets containing animal protein (Menge, Combs, Hsu \& Shorb, 1952; Patterson \& McGinnis, 1954; Waibel et al. 1955; Barnett \& Bird, 1956); others have shown that depletion of the hens had no effect on the response of their progeny to unidentified growth factors (Sunde, Vedvik, Bruins \& Cravens, 1952; Lillie et al. 1953; Fisher, Scott \& Hansen, 1954). The results of our experiments with normal birds suggest that the growth-promoting effect of fish solubles did not depend on a state of depletion of any factors associated with animal protein. Nor, surprisingly, did it depend on the absence of animal protein from the chick's diet, since normal and depleted chicks both grew significantly better when the normal diet was supplemented with the solubles; in fact the magnitude of response was greater on the normal than on the vegetable-protein diet (see Table 3 ).

It is now generally accepted that dietary antibiotics increase growth through an effect on the intestinal microflora. The idea that fish solubles may also influence organisms in the gut has arisen because there is some similarity between the pattern of response to fish solubles and that to antibiotics. For instance, in the course of 3 years' work, Barnett $\&$ Bird (1956) reported a range in growth effect of fish solubles of from $-10 \%$ to $+46 \%$, and also noted that small responses appeared to arise when chicks not given supplements grew well and, conversely, that large responses were associated with relatively poorer growth. During our work we also gained this impression, but were unable to establish the relationship with full confidence; in the twenty-eight experiments with depleted chicks given vegetable-protein diet, the correlation coefficient between the weights of the chicks given the unsupplemented diet and the magnitude of the response to fish solubles was $-0.315(P=0.1)$. In the experiments of Barnett \& Bird (1956) the loss of response to fish solubles occurred in their laboratory at about the same time as the disappearance of the growth-promoting effects of antibiotics. Further, the response to fish solubles was restored when the birds were given chick droppings in the diet, because the weight of the groups not receiving fish solubles was thereby depressed. This apparent analogy betwcen the effects on growth of fish solubles and of antibiotics seemed to deserve further study, 
and in the later experiments we included, when possible, groups of chicks given penicillin alone or in combination with the solubles. From the results of these trials two effects became apparent. First, there was a similarity ir. the size of growth response to each material in any one experiment, as illustrated in Fig. I. Secondly, the growthpromoting activity of fish solubles and penicillin were independent and additive (Table 3). If, therefore, the growth response to fish solubles is the result of a change in gut flora, it seems likely that the organism(s) affected by fish solubles are different from those affected by penicillin. We believe, however, that our findings are compatible with the suggestion of Waibel et al. (1955) and Barnett \& Bird (1956) that one mode of action of fish solubles may be by modification of the gut flora, and studies are in progress in this laboratory with germ-free chicks in the hope of resolving this aspect of the problem.

\section{SUM M A R Y}

I. In thirty-nine experiments groups of eight to twelve chicks were given either a diet containing proteins of vegetable origin only or a more usual chick mash, to test the growth-promoting activity of condensed herring solubles.

2. A supplement of $5 \%$ solubles to both diets significantly increased the weight gains of chicks, whether they originated from hens given a vegetable-protein diet or those given a practical breeder's mash.

3. 'The growth-promoting activity was divided equally between water-soluble and water-insoluble portions of the herring solubles.

4. The pattern of response to fish solubles was similar to that to penicillin. When the two supplements were given together, their combined effect was equal to the sum of the effects of each supplement alone.

5. The hypothesis that fish solubles may promote growth by modification of the alimentary microflora is discussed in the light of these results.

We are grateful to our colleague, Miss Z. D. Hosking, for statistical analysis.

\section{REFERENCES}

Barnett, B. D. \& Bird, H. R. (1956). Poult. Sci. 35, 705.

Duncan, D. B. (1955). Biometrics, II, I.

Fisher, H., Scott, H. M. \& Hansen, R. G. (1954). Y. Nutr. 52, r 3.

Fuller, II. L., Carrick, C. W. \& Hauge, S. M. (1952). Poult. Sci. 31, 473.

Kramer, C. Y. (1957). Biometrics, 13, 13.

Lillie, R. J., Sizemore, J. R. \& Bird, H. R. (1953). Poult. Sci. 32, 855.

Mason, M. E., Sacks, J. \& Stephenson, E. L. (1961). F. Nutr. 75, 253.

Menge, H., Combs, G. F., Hsu, P. T. \& Shorb, M. S. (1952). P(iult. Sci. 3r, 237.

Menge, H., Denton, C. A., Sizemore, J. R., Lillie, R. J. \& Bird, H. R. (1953). Poult. Sci. 32, 863.

Patterson, E. B. \& McGinnis, J. (1954). Fed. Proc. 13, 472.

Steinke, F. H., Bird, H. R. \& Strong, F. M. (1963). F. Nutr. 80, 60.

Sunde, M. L., Cravens, W. W., Elvehjem, C. A. \& Halpin, J. G. (1950). Poult. Sci. $29,204$.

Sunde, M. L., Vedvik, J. R., Bruins, A. W. \& Cravens, W. W. (1952). Poult. Sci. 3r, 57r.

Waibel, P. E., Morrison. A. B. \& Norris, L. C. (1955). Poult. Sci. 34, 1322. 